\title{
Migrants Community in the Republic of Tatarstan: The Strategies of Adaptation and Relations with the Host Population
}

Tatiana Titova

PhD, Doctor in History, Full Professor, Kazan (Volga region) Federal University tatiana.titova@rambler.ru

\section{Elena Frolova}

PhD in History, Associate Professor, Kazan (Volga region) Federal University elenaieup@mail.ru

Valery Yakovlev

PhD, Doctor in History, Head of Department, Kazan State Conservatory (Academy) Named after N.G. Zhiganov; jakinstr@mail.ru

Doi:10.5901/mjss.2015.v6n6s5p280

\section{Abstract}

The importance of the problem under investigation is due to the need of thorough research of the complicated issues associated with the adaptation of migrant workers in the host society. All these issues are of great social, economic, political and cultural significance for the modern Russian society in general, and the Republic of Tatarstan in particular. The strategies of migrant integration into the host society, as well as the social and cultural processes taking place within migrant communities have been undergoing a serious reconsideration and research. The purpose of the research is to analyze the adaptation strategies of migrants and the main features of their interaction with the host population. The analyzed materials have been gathered using the methods of opinion poll, as well as biographical and semi-structured interview. As a result there have been analyzed the degree of intra-group cohesion of migrants through their social contacts and attitude to intermarriage. The factors obstructing the migrant interaction with the local population have been also reviewed within the conducted research. Special attention was given to the way the respondents assess the attitude of the local population toward migrants. Overall, the social and cultural features of migrants have a great impact on the successfulness of their adaptation to the host society. The data and results of the conducted research presented in the article might be useful to anthropologists, social and cultural anthropologists, political scientists, migration and interethnic cooperation department representatives.

Keywords: adaptation strategy, migrant communities, migrant integration, host society, host population, intra-group cohesion.

\section{Introduction}

\subsection{The research relevance}

Labour migration is of exceptional economic, social, political and cultural significance in the modern world. Transport accessibility, high level of financial relations and open borders have become a basis of everyone's right to freedom of movement and changing of life. Nowadays labor migration is one of the main ways of social mobility. Migration processes occupy a central position on the agenda of state policy, media, and scientific conferences. Migration has become not only a part of the people's daily and professional lives, but also is a basis of a wide range of controversial and disputable issues to be studied in the nearest future.

\subsection{An overview of the recent research}

The research of labor migration deals with several scientific fields. The demographers are interested in statistical analysis of migration flows. First of all they are focused on the contribution of migration to the demographic processes (reproduction and the overall growth of the population) and the change in the structure of the population and its characteristics (aging, gender balance, life expectancy, the diseases features and so on.) (Chudinovskikh, 2004). 
Migrants mostly belong to the category of the working population and play a significant role in the labor market of human resources. In this regard, such features as professional, age and sex structure of migration flows are of great interest to the economists. The subject of economic analysis is the contribution of migrants to the GDP of the countries of origin and the host countries; the direction of migrant movement (to Russia, to some foreign countries or within the regions of the country); the transformation of economic sectors, which employ a significant number of migrants; and economic regulation mechanisms of the process of migration (Abashin, 2007-2008). The research of everyday practices of migrants is a vital part of scientific work of the anthropologists and sociologists. A great deal of attention is given to the internal and external factors of migration (the so-called push- and pull- factors). The researchers appeals to the mechanisms of migration - how people choose the strategy of moving, what type of residence they are to prefer (short-period of staying or long-term habitation), what resources are needed for the move, which means of communication are used to maintain the connection with the family and within the migrant community (Titova and others, 2013). Considerable part of research is devoted to the problems of adaptation and characteristics of the host society, for example, the level of xenophobia in the countries where migrants go to work; if there are any mechanisms of adaptation and integration of newcomers and so on (Brednikova, 2003). Nevertheless, the study of life strategies of migrants in the regions of Russian Federation requires deeper level of analysis. In this article the main issues of the adaptation strategies of representatives of migrant communities in the Republic of Tatarstan are presented by a group of researchers.

\section{Methods}

\subsection{The purpose and objectives of the research}

The main goal of the research is to give a comprehensive analysis of adaptation strategies and interaction with the local population of the migrant communities in the Republic of Tatarstan. The general research objectives are as follows:

- to analyze the degree of intra-group cohesion of migrants;

- $\quad$ to consider the factors obstructing the migrant interaction with the local population;

- $\quad$ to reveal how the respondents assess the attitude of the local population toward migrants.

\subsection{Theoretical and empirical methods of the research}

Multiparadigmatic approach is used as a basic approach to the study of the problem. It is supplemented by the theory of nationalism (Gellner, 2009, Hobsbawn, 1983), socialization (Berger, Lukman, 1995), as well as the concept of "social organization of cultural difference" F. Barth (Barth, 1989).

The research is based on the analysis of empirical material collected in 2015. The data has been collected by means of a survey conducted among the representatives of the diaspora; observations; and semi-structured biographical interviews. The collected empirical data is interpreted according to the principles of so-called "thick description", i.e. the analysis is based on the terms of the informants.

\subsection{The base of the research}

Within the survey there have been interviewed 300 migrant workers from Uzbekistan, Azerbaijan, Kyrgyzstan and Tajikistan who have come to the Republic of Tatarstan (2015). 10 interviews with the representatives of the diaspora have also been conducted.

\section{Results and Discussion}

\subsection{The characteristics of the research object}

The total number of the respondents is 300 people who have a valid residence permit in the city of Kazan. Of the total number of the respondents $69.3 \%$ are men and $30.7 \%$ are women. The respondents are the representatives of the most numerous migrant communities of the Republic of Tatarstan: the Azerbaijanis, the Tajiks, the Uzbeks and the Kyrgyz.

Most of the Kyrgyz and Uzbeks respondents, two thirds of the Tajiks respondents and nearly half of the Azerbaijanis respondents are married. However, if most of the Azerbaijani and Kyrgyz respondents are married officially (in the registry office), the majority of the Tajiks and Uzbeks respondents are married in both ways, officially and according to the canon of their religion. Every tenth Uzbek respondent and every twelfth Tajik respondent are married 
only according to the canon of their religion.

The longer is the period of migrants' accommodation in the host city the more successful is their integration into the host society. $7 \%$ of the respondents have lived in the city for less than 1 year, $38.7 \%$ of the respondents have lived in the city of Kazan from 1 to 3 years; $32.7 \%$ - from 3 to 5 years; $12.7 \%$ - from 5 to 10 years, $9 \%$ - more than 10 years or they are the natives of the city. It should be noted that the Kyrgyz and the Azerbaijani respondents have got the longest period of residence in Kazan (14.6\% of the Kyrgyz and $12 \%$ of the Azerbaijanis have lived in the city more than 10 years, or they are natives of the city, while the share of such respondents as Tajiks and Uzbeks is $5.3 \%$ and $4 \%$, respectively). A high proportion of the Tajiks and Uzbeks respondents e have lived in the city from 1 year to 3 years (49.3\% and 54.7\%, respectively). The greatest number of respondents having less than 1 year of residence in the city is the Tajiks (16\%).

\subsection{Intragroup cohesion and attitude toward interethnic marriage}

All the respondents demonstrate a high level of intragroup cohesion. In the sphere of the respondents' social contacts, kinship plays a dominant role. The vast majority of the respondents (85\%) say that they maintain close relationships with the representatives of their own nationality, and one in ten respondents stays in touch, "communicates from time to time". Meanwhile, men choose the position "maintain close relations" more often than women ( $88 \%$ and $78.3 \%$, respectively). When dealing with some difficult situation, the respondents tend to look for support in kinship relations: for example, in a difficult situation the respondents first of all ask their relatives for help, second place takes "friends", the third place is given to "the community" (the Kyrgyz select the last option twice as often as the representatives of the other ethnic groups).

In the sphere of friendly relations the respondents are also oriented toward the mono-ethnic interaction: $86.7 \%$ of the respondents have a closest friend of their own nationality. Friendly relations with the local population are supported by $68 \%$ of the respondents (women are more often than men - $75 \%$ and $64.9 \%$, respectively). The number of friends among the local population also varies depending on the respondents' ethnicity, so if $98.7 \%$ of the Azerbaijanis and $93.3 \%$ of the Kyrgyz have friendly relations with the local population, the share of such respondents among the Uzbeks and the Tajiks is $54.7 \%$ and $25.3 \%$, respectively. The respondents state that they maintain friendly relations mainly with the Tatars, or "with the Russians and the Tatars equally".

Thus, the Tajik and the Uzbek respondents show the highest level of distancing from the local population, while the Kyrgyz and the Azerbaijanis are more focused on the integration strategy of adaptation.

These trends are confirmed by the respondents' attitude toward the issue of marriage with the representatives of the other nationalities. $66.7 \%$ of the Uzbek respondents, $40 \%$ of the Tajik respondents, $21.3 \%$ of the Azerbaijani respondents and $13.3 \%$ of the Kyrgyz respondents strongly disapprove the marriage of their relative with a representative of some other nationality. The option "would approve" is chosen by the Azerbaijani respondents (28\%), while the option "would not approve, but would not mind" - by the Kyrgyz respondents. Hence, the Azerbaijani and the Kyrgyz respondents are more likely to interact with the local population (friendly contacts and marital relations).

Taking into consideration the gender factor we can see that the attitude towards marital relations with a representative of some other nationality depends on the sex of the respondent, women choose the option "would approve" more often than men (18.5\% of women and $13 \%$ of men) and the same is for the option "would not approve, but would not mind" (18.5\% of women and $13.5 \%$ of men); whereas men are characterized by the categorical position "absolutely would not approve" (26.1\% of women and $39.4 \%$ of men).

From the interview (int. - the interviewer; res. - respondent):

Int.: "Are you ready to accept a person of another nationality as a close relative?"

Res.: "I think I am, but, as they say, you do not know until you see. My children have not yet chosen a partner, but I hope they will choose a person of similar culture and religion. I think it will make their future life happier" (the Uzbek respondent, a woman, 51).

Thus, the results of the research show that, at first sight, the male migrants demonstrate a higher level of intragroup cohesion. This is due to their closer contact with the representatives of their own nationality, fewer connections with the local population and a categorical attitude toward interethnic marriages.

However, it should be noted that for the most of the interviewed migrant women the scope of their meaningful social contacts is limited and includes mostly their relatives. Three quarters of the female respondents, regardless of the period of their accommodation in the country and their marital status, state that they turn to their relatives for support in case of a difficult situation. The analysis of the migrant women friendly relations also confirmed that most of them are based on social contacts in a mono-ethnic environment. Despite the fact that the majority of the female respondents have some friends among the local population, a significant part of the respondents admit that their friends are mostly of their 
own nationality. The main reason for friendly contacts of women migrants with the local population is their working together.

Thus, the data of the research draw us to the conclusion that among the migrants, primarily the Tajiks and the Uzbeks, the predominant orientation is to the ethnic insularity: the social contacts are carried out mainly within the circle of their relatives and the people of their own nationality, and the intermarriage is strongly disapproved. More than that, these factors lead to the preservation of the ethnic community isolation, and to the increasing of cultural distancing from the local society. The consequences of such trends could lead to the migrant rejection by the host society and to the growth of xenophobia. The Azerbaijanis and the Kyrgyz demonstrate a successful strategy of integration into the host society, which is reflected both in the sphere of social contacts, and in relation to interethnic marriages.

\subsection{Leisure activities preferences}

To some extent leisure activities preferences demonstrate the degree of integration of the Azerbaijani and the Kyrgyz respondents into the host community. So, more than $60 \%$ of the Azerbaijanis, $70 \%$ of the Kyrgyz, $20 \%$ of the Uzbeks and $10 \%$ of the Tajiks go to the movies, theatres and concerts. Watching TV as one of the leisure preferences is also a supporting argument for that. The fact of watching television programs proves the migrants' interest in the host society and their desire to have relevant information about the country they live in. So, about $80 \%$ of the Uzbeks, $70 \%$ of the Kyrgyz, $45 \%$ of the Azerbaijanis and $23 \%$ of the Tajiks spend their free time watching television programs.

The Azerbaijani, the Kyrgyz and the Tajik respondents also maintain close kindred relationships and friendly contacts. About $80 \%$ of the Kyrgyz, $65 \%$ of the Azerbaijani, $53 \%$ of the Uzbek and $16 \%$ of the Tajik respondents visit their friends and relatives and communicate with them in their free time. More than a half of the Uzbek respondents, every fourth Tajik respondent, every fifth Azerbaijani respondent and every ninth Kyrgyz respondent communicate with their countrymen in their free time.

The respondents are also active users of the Internet: about $50 \%$ of the Azerbaijanis and the Kyrgyz, approximately $40 \%$ of the Uzbeks and over $20 \%$ of the Tajiks.

Reading as a pastime activity is not of high priority among leisure preferences (both fiction and the periodical press). More interest in reading is declared by the Azerbaijanis and the Kyrgyz. 17\% of the Azerbaijanis and about 10\% of the Kyrgyz read fiction in their free time comparing to very few Tajiks and Uzbeks. $16 \%$ of the Azerbaijanis, $17 \%$ of the Kyrgyz, and less than $10 \%$ of the Tajik and the Uzbeks spend their free time reading newspapers and magazines. Religious literature is read by $15 \%$ of the Azerbaijanis, by a very small number of the Kyrgyz and the Uzbeks; the Tajiks do not read any religious literature.

Despite the difference in the reader preferences of the respondents, the classical literature (including modern and national ones) dominates in the list of the books read for the last half a year. Among the literary works read by the Azerbaijanis more than a half belongs to classical literature, $30 \%$ is entertaining literature; some of them are of educational and scientific character. The Tajiks and the Uzbeks prefer classical literature (including national one). In the list of the books read by the Kyrgyz there are literary works in national language and scientific literature.

Among the respondents the considerable share of readers is made by women who have specified preferences (in the reader list of entertaining literature made by the Azerbaijani respondents sentimental novels take the first place; in the reader list made by the Kyrgyz respondents a quarter of literary works have a gender component in the title.

Among the most popular periodicals there is a newspaper "Arguments and Facts", "Pro Gorod', a magazine "Our House is Tatarstan". Also every group of the respondents points out "Zamandash" magazine.

Taking part in religious actions and celebrations is one the least probable way of spending free time for the respondents. An explanation for it can be found in the previous researches. During the in-depth interviews the Azerbaijani respondents marked out that visiting a mosque has exclusively religious character and can't be a kind of leisure action for them: "They read the Mohammedan prayer and left - they couldn't stay there. There is no such practice in Azerbaijan - to stay after the Mohammedan prayer in a mosque to talk. The mosque is used to come in, to pray and leave" (the Azerbaijani respondent, a man, 51).

\subsection{Interaction problems with the host population}

All the described above tendencies are also confirmed by the analysis of subjective estimation of the respondents concerning interaction problems with the host population. The contacts with local population are estimated most positively by the Azerbaijanis and the Kyrgyz. More than a half of the Azerbaijani respondents and a third of the Kyrgyz respondents declare that they have no difficulties in communication with the local population. As to the Uzbeks the share 
of such respondents is $18.7 \%$, and the Tajiks' is only $8 \%$.

The fifth part of the Azerbaijanis and the Tajiks and the third part of the Uzbeks consider that their relationship with local population is complicated because of bad knowledge of language; $28 \%$ of the Uzbeks, $17.3 \%$ of the Tajiks, $14.7 \%$ of the Azerbaijanis consider their nationality as the main reason of complicated relationship with the local population. Third of the respondents - the Uzbeks, every tenth Azerbaijani and 8\% of the Tajiks consider psychology features of locals as a source of arising difficulties; the difference in religious behavior and religious life is important for $12 \%$ of the Uzbeks and 9.3\% of the Azerbaijanis. Two thirds of the Kyrgyz respondents can't formulate the reason unambiguously and find it difficult to answer.

When estimating the attitude of the local population toward migrants $47.2 \%$ of the respondents consider it as positive. Every fifth respondent considers local population attitude toward migrants negative. Most of the Uzbek respondents and the Tajiks respondents choose the last option ( $45.3 \%$ and $31.1 \%$ respectively).

Thus, based on the analysis of social contacts and the subjective estimation of the respondents, we can conclusion that the Azerbaijani respondents and the Kyrgyz respondents show high level of integration and cultural tolerance to the host society while the Tajiks and the Uzbeks maintain close relationships within their ethnic groups.

The respondents' orientation toward integration is reflected also in their readiness to follow legislative norms of the host society. Having got into a difficult situation of $53.3 \%$ of the Azerbaijanis, $61.3 \%$ of the Kyrgyz and Tajiks and $13.3 \%$ of the Uzbeks would prefer to follow the official legislation of the Russian Federation. More than a half of the Uzbek respondents and every tenth Tajik would follow the traditional norms of their nationality. The "religious norms of their own religion" option has been chosen by $22.7 \%$ of the Azerbaijanis, $14.7 \%$ of the Tajiks, $8 \%$ of the Kyrgyz and $6.7 \%$ of the Uzbeks.

Thus, keeping the national traditions is more typical for the Uzbek and the Tajiks, following the religious norms is more typical for the Azerbaijanis and the Tajiks.

The process of increasing of migration stream can be considered as a certain challenge for the host country as migration is always followed by a number of factors (for example, higher share of illegal employment, ethno cultural practice) which can affect the structure of the host society.

\section{Conclusion}

The outcome of the research is as follows.

1. The tendency to the ethnic isolation remains among the migrants (mostly among the Tajiks and the Uzbeks): a great deal of the migrants' social contacts is carried out generally within the family circle of relatives and people of the same nationality, the international marriages are strongly disapproved. These factors maintain the steady isolation of the ethnic community, the cultural distance from the host society. The situation of migrants' rejection by the host society and the growth of xenophobia could be the consequences of the above tendencies. The Azerbaijanis and the Kyrgyz show more successful strategy of integration into the host society. It is reflected in the sphere of social contacts and the relation to international marriages.

2. The Uzbeks and the Tajiks are more inclined to determine the locals' attitude toward the migrants as negative whereas the Azerbaijanis and the Kyrgyz are more positive. Thus, more than a half of the Azerbaijanis and a third of the Kyrgyz note that they don't have any difficulties in communicating with the local population. The Uzbeks more often consider that the bad knowledge of language and their own national identity are the reasons of communication difficulties.

3. Based on the analysis of social contacts and subjective estimation of the respondents, it is possible to draw a conclusion that the Azerbaijans and the Kyrgyz show big integration and cultural tolerance to the host society, at the same time the Uzbeks and to a lesser extent the Tajiks maintain close relationships within their ethnic groups.

\section{Acknowledgments}

The work is performed according to the Russian Government Program of Competitive Growth of Kazan Federal University. 


\section{References}

Abashin, S. (2007-2008). Ekonomicheskie migrant iz Tsentral'noy Azii: issledovanie transformatsii identichnosti, norm povedeniya i tipov sotsial'nikh svyazey. Saint Petersburg: CISR.

Barth, F. (1989). Analysis of Culture in Complex Societies. Ethnos, 4, 120-142.

Berger, P.L. Lukman, T. (1995). The Social Construction of Reality: A Treatise on the Sociology of Knowledge. Academia-Center-Media. Brednikova, O. (2003). Dzenskaya trudovaya migratsiya: smena gendernykh kontaktov? Gendernye otnosheniya v sovremennoy Rossii. Samara: Samara University press.

Chudinovskikh, O. (2004). Prichiny i posledstviya krizisa Rossiyskoy migratsionnoy statistiki. Otechestvennye zapiski, 4, 176-190.

Gellner, E. (2009). Nations and Nationalism. Cornell University Press.

Hobsbawn, E. (1983). Invention of Tradition. Cambridge University Press.

Titova, T., Kozlov, V., Frolova, E. (2013). Diaspory i soobschestva migrantov v Respublike Tatarstan: etnosotsiologicheskie ocherki. Kazan: Mir bez granits. 